\title{
PROVISION OF BUSINESS INFORMATION SERVICES BY PUBLIC LIBRARIES TO SMALL- SCALE BUSINESS ENTERPRISES
}

\author{
Paul M. Gichohi \\ https://orcid.org/0000-0003-1593-4642 \\ Kenya Methodist University \\ pmakuster@googlemail.com
}

\author{
Omwoyo B. Onyancha \\ https://orcid.org/0000-0002-9232-4939 \\ University of South Africa \\ onyanob@unisa.ac.za
}

\section{Frankwell Dulle}

https://orcid.org/0000-0003-2016-6596

Sokoine University of Agriculture, Tanzania

fwdulle@suanet.ac.tz

\section{ABSTRACT}

This study explored the business information services offered to small-scale business enterprises (SBEs) by public libraries in Meru County, Kenya. Public libraries are community information centres, hence well-placed to serve the small-scale business community. A quantitative approach and survey research design were adopted. Data were collected from 296 SBE traders and 20 staff members from three public libraries in Meru County using well-structured questionnaires and interviews. Quantitative data were analysed with the help of SPSS software while a thematic analysis was used on qualitative data. The provision of business information services to SBEs in public libraries was in a desolate state owing to inadequate business collections, the lack of sufficient information and communications technology (ICT) facilities, poor awareness of business information services, a poor reading culture, and weak collaborations of public libraries with stakeholders. There is an indispensable need to establish insightful and holistic business information services at public libraries and to institute measures that would foster their utilisation by SBEs. This can be achieved by elevating library facilities, enhancing outreach programmes, ensuring adequate funding, engaging knowledgeable business services librarians, embracing ICT in service delivery, and by having an appropriate policy framework.

Keywords: business information; information for development; business information services; public libraries; small-scale business enterprises; services to SMEs

\section{UNISA}




\section{INTRODUCTION}

Small-scale business enterprises (SBEs) have unique characteristics and features as outlined by Forsman and Temel (2011), Carter and Jones-Evans (2012) Gichohi, Onyancha and Dulle (2016). SBEs are like the engine for local and national economic growth in both developed and developing countries (Chiware 2007). They have occasioned tremendous growth and development in the Dubai market in the United Arabs Emirates (UAE). In Kenya, they contribute immensely to national income, job creation and the eradication of poverty (KIPPRA 2013).

Although SBEs are critical in national development, they encounter an unstructured provision of business information services in Kenya. Gichohi, Onyancha and Dulle (2016) reported a myriad of critical business information needs of SBEs that cut across all stages of business growth, the majority of which can be dealt with through the provision of business information services. In this paper, we adapt the definition of business information service by Chiware (2007) who describes it as the organised information services to the business community in various areas such as financing, available business opportunities, management, marketing, production, business development, and technology. Business information services are significant in enhancing competitiveness, justifying sustainability and fostering the development of business ventures (Chiware 2007, 136, 139). They enable potential investors to be aware of the market conditions, industry success factors, available networks, and reveal the tested approaches to particular businesses.

Existing literature such as by Okello-Obura et al. (2007) indicate that the provision of business information services helps to bridge the skills gap in information retrieval. It affords business people the opportunity to get synthesised information that is specific to their needs. Smith (2009) acknowledges that providing business information services is a challenging task owing to the unique needs of SBEs. Allen (2011) discussed the challenges that affect providers of business information from Europe's context, and singled out technology and budgetary constraints as a major challenge. Chiware (2007) identified language as one of the key problems facing the provision of business information services in Namibia. A similar challenge was identified by Underwood in the Western Cape in South Africa (Underwood 2009). According to Kinnell, Feather and Matthews (1994), the provision of business services in China was hampered by poor communication infrastructure, unavailability and poor utilisation of business information resources, poor coordination in government agencies, the lack of information awareness in the community, and a weak national information policy.

The report of research projects in Yorkshire and the North West in northern England by Wilson and Train $(2006,51-52$,) identified problems faced by business information services. The report identified problems that included: the cost of subscription services in relation to the usage, the absence of rigorous business community profiles, the lack of awareness and requisite business skills and expertise, understaffing, budgetary constraints, and politics. The report emphasised the need for collaboration and 
networking with regional and sub-regional authorities in the dissemination of business information. The report did not, however, describe in precise terms the specific measures needed at public libraries to improve the situation.

\section{THE PROVISION OF INFORMATION SERVICES TO SBES BY PUBLIC LIBRARIES}

A public library is an organisation that offers information services to the public and that is operated by information professionals who are civil servants (Otike 2004). As institutions funded and maintained by government and communities, public libraries have the responsibility of disseminating community information to the public. Van Heerden and Krishna (2013) describe public libraries as the local gateway to knowledge for community development.

Conventionally, the provision of business information services used to be outside the scope of many public libraries. However, with the evolving world, public libraries cannot continue to be non-inclusive or offer services using the conventional approaches and unresponsive mechanisms. Notably, the turbulent world requires coherent and strategic responses that point out the need for public libraries to come up with new structures and systems of dealing with the information needs of specialised groups such as the small-scale business community.

In 2001, IFLA and UNESCO issued a new directive for public libraries that required them to start offering various information services tailored to specific community needs. Such services included information access, training schemes, reading promotion schemes, personal development, and services aimed at children and young people (Dos Santos 2009, 2). With this directive, some public libraries have since come up with different and innovative services to support community development. However, this initiative is not widespread. It has been curtailed by changing market conditions, ICT, changes in information searching behaviour, and users' changing perceptions of the library (Wilson and Train 2006, 51).

In this study, the concern of public libraries providing business information to SBEs is worthwhile. Few studies have linked business information services to businesses' success and long-term survival. A good example is the study by Ucbasaran et al. (2010), which reported a positive relationship between information searches and identification of business opportunities in habitual entrepreneurs compared to novice business people. This implies that the people who are already in business may search and utilise business information services more than those who are intending to start. The novice entrepreneurs could be suffering from the lack of awareness and hence the low utilisation. However, a service that offers business information is critical in reducing uncertainty in business decision-making, recognising business opportunities, achieving high returns on investment, building competitive capabilities and networks, promoting 
the generation of new ideas, scaling down the operational costs, and improving the quality of products and services (Urban Libraries Council 2007).

Existing literature shows how some public libraries have made commendable progress in providing information services to the business community. For example, during the economic downturn in 2008, most public libraries in the USA were reported to have started offering information services to job seekers on available jobs and careers (Wilson 2013). A recent survey by the American Library Association (2015) found that nearly all (97.5\%) public libraries in the USA offer free wireless Internet access; an initiative that has enabled small to medium-sized enterprises (SMEs) to access business information conveniently. Moreover, the Online Computer Library Center (OCLC) (2011) carried out a survey in Canada by inviting 159 librarians via a post on various email lists to answer a questionnaire gauging the use of their public libraries for jobseeking, small business support, meeting room usage and other activities. The results indicated that at Canadian public libraries, business owners and employees use resources 76000 times every month to support their small businesses (OCLC 2011). The report also established that public libraries in Canada offer career and job-search information to approximately 204000 individuals. Nearly 200 public libraries were reported to have meeting rooms, which were being used by over 28000 people every month. The survey, however, relied on data collected from public library staff eschewing the collection of data from users.

In the United Kingdom, the provision of business information services is done by public libraries such as the British Library and other dedicated business information centres (Kinnell, Feather, and Matthews 1994, 20). Business information services were also noted in Japan (Hosono 2006, 129). According to Hosono, some of the information services offered by Japanese public libraries include reference services and regular seminars.

In the African context, public libraries are yet to fully embrace and deal with the information needs of the business community. As observed by Mutshewa $(2009,18)$, many public libraries are predominantly serving students. This makes it difficult for public libraries to attract the rest of the community groups such as the small-scale business community. The Western Cape in the Republic of South Africa embraced the idea of providing business information services by establishing business corners in public libraries (Underwood 2009, 570-571).

In Kenya, public libraries that were established after April 1965 are expected to enhance access to socio-economic information. However, they are rarely utilised by the business community. This study was interested in examining the nature of the provision of business information services to SBEs by the three public libraries in Meru County, namely the Meru District Library, the Mikumbune Community Library and the Timau Community Library. Meru County had only three public libraries by the time this study was conducted. In Kenya, all public libraries are centrally administered by the Kenya 
National Library Service (KNLS), a state corporation that is funded by the national government.

According to the Meru County Government (2014), Meru County has high agricultural potential that is attributed to the many small-scale agribusiness ventures, hence the need for supportive business information services. Notably, the practices of public libraries supporting education in primary and secondary schools are widespread in Meru County. However, a balanced approach to community development is paramount considering that the growth of the local economy in Meru County is precipitated by the development of SBEs (Ministry of Devolution and Planning 2013). The study is therefore very significant in exposing the unexploited opportunities by public libraries in serving the small business community.

\section{STATEMENT OF THE PROBLEM AND PURPOSE OF THE STUDY}

Although public libraries have the crucial mandate of contributing to community development in Kenya, they lack a structured and uniform approach to the provision of business information services to the SBEs. Unlike Australia, the Netherlands and Canada where the dissemination of business information is a common task of public libraries, Dos Santos (2009) and Mutshewa (2009) recognise that public libraries in Africa are yet to fully embrace the provision of socio-economic information. In a study by Electronic Information for Libraries (EIFL and TNS RMS East Africa 2012) it is reported that public libraries in Kenya are mainly supporting the education system; hence this study noted a gap in the way public libraries in Meru County serve the SBEs. The SBEs lack equal access to business information and related services, which is occasioned by the absence of proper systems and structures in the provision of business information. Available literature such as by Mutshewa (2009) and Underwood (2009) have provided very scanty information, especially from developing countries.

The study was therefore set out to explore the nature of business information services offered by public libraries to SBEs in Meru County, Kenya. This was realised through the following objectives:

- finding out how often SBEs were using public libraries for business information in Meru County;

- identifying challenges faced by SBEs in accessing business information at public libraries in Meru County;

- ascertaining approaches and practices public libraries use to provide business information services to SBEs in Meru County;

- ascertaining the nature of facilities and conditions of public libraries for supporting the provision of business information services to SBEs; 
- identifying challenges encountered by public libraries in providing business information services to SBEs; and

- identifying measures needed at public libraries to improve the provision of business information services.

\section{RESEARCH METHODOLOGY}

This study reports part of the findings from a $\mathrm{PhD}$ study on the role of public libraries in the development of SBEs in Meru County, Kenya, which took place from 2013 to 2016. The positivism paradigm was adopted in exploring the identified phenomena. A quantitative research approach was used whereby a survey research design was adopted to conduct the study. The target population consisted of people who operated small and micro businesses and public library staff who numbered 4 514, and 21 respectively. In order to select a sample suitable for the study, the cluster and systematic sampling techniques were used in obtaining 355 SBEs while a census technique was used on 21 library workers (professional and technical staff). The library workers comprised three branch library directors who were interviewed accordingly while questionnaires were used to collect data from the rest (split 18) of the library staff. SBEs were widely dispersed and as a result, the questionnaire was deemed to be the most appropriate instrument of collecting data. Using the split-half method, the reliability test of the questionnaire showed a high Cronbach's alpha score of 87.7 per cent and 85.3 per cent for even and odd numbers respectively. Quantitative data were analysed using Statistical Product and Service Solutions (SPSS) while a thematic analysis on key concepts and statements was used on qualitative data. The results of the study were presented in tables, charts, and in some cases, descriptive statements were used such as on the background information of respondents. This was a cross-sectional study, hence it was not possible to observe the behaviour of SBEs over time. The population was also widespread hence the mobility challenges in covering SBEs in the interior locations.

\section{RESULTS}

\section{Response Rate and Background Information of Respondents}

This study recorded a high response rate, that is, 296 SBE traders (83.4\%) and 20 staff members from the three public libraries (95\%). The majority of the public library staff were technically qualified and had the requisite experience. A total of 10 staff members $(50 \%)$ had a college diploma, while five $(25 \%)$ had certificates in library studies. Seventeen staff members $(17,85 \%)$ had three or more years of work experience. The 
competence of library staff in terms of qualifications and experience is critical in the provision of business information services at public libraries.

The owners of SBEs in Meru County had a basic education, with 257 (86.8\%) having a Form 4 or Form 6 secondary school certificate, a college certificate and/or a college diploma. This indicated that most SBEs possessed the basic numeracy and literacy skills necessary in understanding business information. Approximately half, 151 (51\%), of the SBEs in Meru County had no business employees, 268 (90.5\%) were sole proprietorships that required little capital and earned a moderate income. However, 195 (65.9\%) SBEs had no background training in business matters. The study further sought to establish the last time SBEs visited a public library for business information and gathered information as shown in Table 1.

Table 1: The last time SBEs visited a public library

\begin{tabular}{|l|l|l|}
\hline Responses $\mathbf{N}$ = 296) & $\begin{array}{l}\text { Number of } \\
\text { respondents }\end{array}$ & Percentages \\
\hline I have never been to a public or community library & 132 & 44.6 \\
\hline More than three years ago & 65 & 22.0 \\
\hline Very often & 32 & 10.8 \\
\hline A year ago & 28 & 9.5 \\
\hline Once in the last three months & 27 & 9.1 \\
\hline Once in the last six months & 12 & 4.1 \\
\hline
\end{tabular}

The results in Table 1 show that most SBEs, 132 (44.6\%), had never been to a public library while 65 (22\%) last visited more than three years ago. Only 32 (10.8\%) of SBEs were using public libraries often for business information. This shows that SBEs rarely visit public libraries for business information.

\section{Challenges Faced by SBEs in Accessing Business Information at Public Libraries in Meru County}

The study sought to identify the challenges encountered by SBEs in accessing business information services at public libraries. The responses to the suggested challenges were ranked according to the majority count and summarised in percentages as shown in Table 2. 
Table 2: $\quad$ Challenges faced by SBEs in accessing business information at public libraries in Meru County

\begin{tabular}{|l|l|}
\hline Challenges (N = 296) & $\begin{array}{l}\text { Value and } \\
\text { Percentages }\end{array}$ \\
\hline Limited skills in searching for information on business & $155(52.4 \%)$ \\
\hline Unawareness of the places and the kind of information sources available & $152(51.4 \%)$ \\
\hline The information obtained does not solve the specific business problems & $150(50.7 \%)$ \\
\hline $\begin{array}{l}\text { The places or providers of business information are far away from business } \\
\text { premises }\end{array}$ & $138(46.3 \%)$ \\
\hline $\begin{array}{l}\text { The information on starting and running a business venture is usually not } \\
\text { given out easily }\end{array}$ & $123(41.6 \%)$ \\
\hline Limited time to visit places that provide business information & $93(31.4 \%)$ \\
\hline $\begin{array}{l}\text { The people who provide business information do not appear to be well } \\
\text { informed }\end{array}$ & $64(21.6 \%)$ \\
\hline
\end{tabular}

More than half $(155,52.4 \%)$ of the SBEs indicated limited skills in searching for business information and low unawareness of the places and the kind of available information sources $(152,51.4 \%)$ as the most serious challenges. The library staff issue of being informed was the least challenge. A total of 93 (31.4\%) SBEs indicated that they had a time challenge of visiting places that provide business information.

\section{Approaches and Practices Public Libraries Use to Provide Business Information Services to SBEs in Meru County}

The study further sought to find out the nature of approaches and practices used by public libraries when providing business information with a view to recommending improvements. Various practices and approaches were provided to library staff, requiring them to indicate the level of agreement using the choices that included: "strongly agree", "agree", "neutral", "disagree", and "strongly disagree". The findings are presented in Table 3. 
Table 3: Approaches and practices on the provision of business information services at public libraries in Meru County

\begin{tabular}{|c|c|c|c|}
\hline $\begin{array}{l}\text { Statement on business information services } \\
\text { in public libraries }(N=20)\end{array}$ & $\begin{array}{l}\text { Score for } \\
\text { both strongly } \\
\text { agree and } \\
\text { agree } \\
n(\%)\end{array}$ & $\begin{array}{l}\text { Neutral } \\
\mathrm{n}(\%)\end{array}$ & $\begin{array}{l}\text { Score for } \\
\text { strongly } \\
\text { disagree and } \\
\text { disagree } \\
\mathrm{n}(\%)\end{array}$ \\
\hline $\begin{array}{l}\text { Our library receives sufficient funding to support } \\
\text { business information sources and services }\end{array}$ & 0 & $2(10.0)$ & $18(90.0)$ \\
\hline $\begin{array}{l}\text { Our library has a website or webpage where } \\
\text { business people interact with information } \\
\text { sources and staff }\end{array}$ & $1(5.0)$ & $1(5.0)$ & $18(90.0)$ \\
\hline $\begin{array}{l}\text { Our library has a Facebook/Twitter/LinkedIn } \\
\text { where business people interact and socialise }\end{array}$ & $1(5.0)$ & $1(5.0)$ & $18(90.0)$ \\
\hline $\begin{array}{l}\text { Our library has a room where business partners } \\
\text { and moneylenders hold meetings free of charge, } \\
\text { provided they book in advance }\end{array}$ & $2(10.0)$ & $1(5.0)$ & $17(85.0)$ \\
\hline $\begin{array}{l}\text { Our library provides selective business } \\
\text { information services to the business community }\end{array}$ & $2(10.0)$ & $1(5.0)$ & $17(85.0)$ \\
\hline $\begin{array}{l}\text { Our library has subscribed to online business } \\
\text { databases }\end{array}$ & $2(10.0)$ & $2(10.0)$ & $16(80.0)$ \\
\hline $\begin{array}{l}\text { Our library has linkages, collaborations, and } \\
\text { networks with local business schools and } \\
\text { research institutions for accessibility of business } \\
\text { research information for the mutual benefit of the } \\
\text { business community }\end{array}$ & $4(20.0)$ & $2(10.0)$ & $14(70.0)$ \\
\hline $\begin{array}{l}\text { Our library maintains a profile that enables } \\
\text { us to know the specific needs of the business } \\
\text { community }\end{array}$ & $2(10.0)$ & $4(20.0)$ & $14(70.0)$ \\
\hline $\begin{array}{l}\text { Our library maintains an online Ask-A-Librarian } \\
\text { service }\end{array}$ & $3(15.0)$ & $3(15.0)$ & $14(70.0)$ \\
\hline $\begin{array}{l}\text { The library offers outreach activities and events } \\
\text { to SBEs }\end{array}$ & $2(10.0)$ & $7(35.0)$ & $11(55.0)$ \\
\hline $\begin{array}{l}\text { Most of the business information sources at our } \\
\text { library are donations }\end{array}$ & $7(35.0)$ & $2(10.0)$ & $11(55.0)$ \\
\hline $\begin{array}{l}\text { Our library has a dedicated business librarian } \\
\text { who is contacted by the business community for } \\
\text { their business information needs }\end{array}$ & $4(20.0)$ & $5(25.0)$ & $11(55.0)$ \\
\hline $\begin{array}{l}\text { Our library provides tailored information services } \\
\text { to business people }\end{array}$ & $3(15.0)$ & $8(40.0)$ & $9(45.0)$ \\
\hline
\end{tabular}




\begin{tabular}{|l|l|l|l|}
\hline $\begin{array}{l}\text { Statement on business information services } \\
\text { in public libraries (N = 20) }\end{array}$ & $\begin{array}{l}\text { Score for } \\
\text { both strongly } \\
\text { agree and } \\
\text { agree } \\
\mathbf{n}(\%)\end{array}$ & $\begin{array}{l}\text { Neutral } \\
\mathbf{n} \text { (\%) }\end{array}$ & $\begin{array}{l}\text { Score for } \\
\text { strongly } \\
\text { disagree and } \\
\text { disagree } \\
\mathbf{n} \text { (\%) }\end{array}$ \\
\hline $\begin{array}{l}\text { Our library has good facilities and equipment } \\
\text { to support small-business people for their } \\
\text { information needs }\end{array}$ & $2(10.0)$ & $\begin{array}{l}11 \\
(55.0)\end{array}$ & $7(35.0)$ \\
\hline $\begin{array}{l}\text { Our library works closely with the county } \\
\text { government, specifically the enterprise } \\
\text { development unit for mutual benefits of the } \\
\text { business community }\end{array}$ & $2(10.0)$ & $\begin{array}{l}11 \\
(55.0)\end{array}$ & $7(35.0)$ \\
\hline $\begin{array}{l}\text { Our library usually purchases additional books } \\
\text { to meet the information needs of the business } \\
\text { community }\end{array}$ & $13(65.0)$ & $2(10.0)$ & $5(25.0)$ \\
\hline $\begin{array}{l}\text { Our library has good or relevant business } \\
\text { information sources }\end{array}$ & $14(70.0)$ & $3(15.0)$ & $3(15.0)$ \\
\hline The collection on business information is old & $14(70.0)$ & $4(20.0)$ & $2(10.0)$ \\
\hline $\begin{array}{l}\text { Our library staff can work at any service points } \\
\text { and offer varied information services to users }\end{array}$ & $16(80.0)$ & $2(10.0)$ & $2(10.0)$ \\
\hline $\begin{array}{l}\text { Our library markets and promotes library } \\
\text { services to the business community }\end{array}$ & $13(65.0)$ & $7(35.0)$ & 0 \\
\hline
\end{tabular}

According to Table 3, the majority of public library staff disagreed that their libraries

- were receiving sufficient funding to support business information sources and services $(18,90.0 \%)$,

- had a website or webpage where business people interacted with information sources and staff $(18,90.0 \%)$,

- had a Facebook/Twitter/LinkedIn account where business people interacted and socialised (18, 90.0\%),

- had a room where business partners and moneylenders hold meetings free of charge, provided they book in advance $(17,85.0 \%)$,

- were providing selective business information services to the business community $(17,85.0 \%)$,

- $\quad$ had subscribed to online business databases (16, 80.0\%), and

- had linkages, collaborations, and networks with local business schools and research institutions for accessibility of business research information for the mutual benefit of the business community $(14,70.0 \%)$. 
Staff respondents, however, showed high agreement scores that their library usually purchases additional books for business community, an option selected by 13 (65.0\%), indicating good or relevant business information sources (70.0\%), and that the collection on business information was old (14, 70.0\%). The result reveals the status and nature of information services provided by public libraries to SBEs, which indicate serious weaknesses and inadequate preparedness.

The study further sought to ascertain the approximate time spent by staff in providing information services to the SBEs traders (see Figure 1).

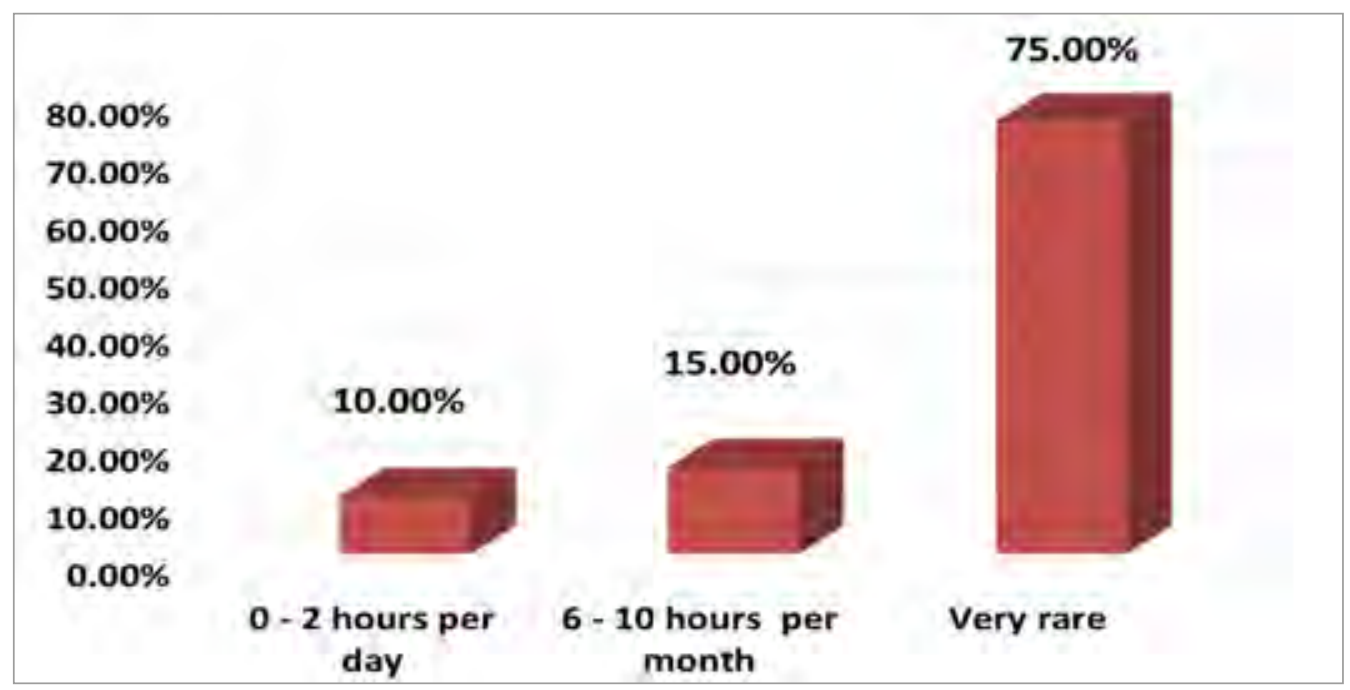

Figure 1: Approximate time spent by staff when providing information services to the small-scale business traders in public libraries, Meru County

Surprisingly, 14 (75\%) of the public library staff rarely provide business information services; three (15\%) spend between six and 10 hours per month, while two (10\%) spend up to two hours a day. A number of factors can explain these results, the main ones being the challenges presented in Table 2 .

\section{Nature of Facilities and Conditions of Public Libraries for Supporting the Provision of Business Information Services to SBES}

In order to understand the nature of preparedness of public libraries in providing business information services, various questions were posed to staff respondents on the nature of facilities, the level of organisation, the design and attractiveness of a library building, staff behaviour, responsiveness, outreach activities, and the nature of resources. Respondents were specifically asked to evaluate 30 aspects of the aforementioned issues 
by rating each of them as "excellent", "good", "poor", "very poor" or "no comment". The results are presented in Table 4. Choices that had no responses were omitted.

Table 4: $\quad$ Nature of facilities and conditions of public libraries for supporting the provision of business information services to SBEs

\begin{tabular}{|c|c|c|c|}
\hline Facilities and conditions at public libraries $(N=20)$ & $\begin{array}{l}\text { Good } \\
\text { n (\%) }\end{array}$ & $\begin{array}{l}\text { Poor } \\
\text { n (\%) }\end{array}$ & $\begin{array}{l}\text { No } \\
\text { comment } \\
\text { n (\%) }\end{array}$ \\
\hline Library opening hours & $20(100.0)$ & 0 & 0 \\
\hline The arrangement of books on the shelves & $20(100.0)$ & 0 & 0 \\
\hline Hospitability and welcoming aspects of the library & $19(95.0)$ & 0 & $1(5.0)$ \\
\hline The appearance of library staff & $19(95.0)$ & 0 & $1(5.0)$ \\
\hline Librarians' competence & $19(95.0)$ & 0 & $1(5.0)$ \\
\hline Number of books & $18(90.0)$ & $1(5.0)$ & $1(5.0)$ \\
\hline $\begin{array}{l}\text { Librarians' responsiveness when they are responding } \\
\text { to general queries from library users }\end{array}$ & $18(90.0)$ & $2(10.0)$ & 0 \\
\hline Library facilities and equipment & $17(85.0)$ & $3(15.0)$ & 0 \\
\hline Colour used on the walls of the library & $17(85.0)$ & $3(15.0)$ & 0 \\
\hline Outreach programmes and activities of the library & $17(85.0)$ & $3(15.0)$ & 0 \\
\hline Public goodwill & $17(85.0)$ & $3(15.0)$ & 0 \\
\hline The exterior design & $16(80.0)$ & $4(20.0)$ & 0 \\
\hline $\begin{array}{l}\text { The arrangement of seats, tables, shelves, and } \\
\text { computers }\end{array}$ & $16(80.0)$ & $4(20.0)$ & 0 \\
\hline Librarians' expertise in working with computers & $16(80.0)$ & $3(15.0)$ & $1(5.0)$ \\
\hline $\begin{array}{l}\text { Librarians' responsiveness when they are requested } \\
\text { to assist with the use of computers }\end{array}$ & $16(80.0)$ & $3(15.0)$ & $1(5.0)$ \\
\hline The interior design of service points & $15(75.0)$ & $5(25.0)$ & 0 \\
\hline $\begin{array}{l}\text { Events, activities and occasions organised by the } \\
\text { library }\end{array}$ & $15(75.0)$ & $5(25.0)$ & 0 \\
\hline Nature and ambience of recreation facilities & $14(70.0)$ & $5(25.0)$ & $1(5.0)$ \\
\hline Kinds of journals, magazines and newspapers & $14(70.0)$ & $5(25.0)$ & $1(5.0)$ \\
\hline Library space & $13(65.0)$ & $7(35.0)$ & 0 \\
\hline The design of the library's website & $13(65.0)$ & $1(5.0)$ & $6(30.0)$ \\
\hline Nature and ambience of the toilets in the library & $13(65.0)$ & $6(30.0)$ & $1(5.0)$ \\
\hline Nature and ambience of the adult section of the library & $13(65.0)$ & $6(30.0)$ & $1(5.0)$ \\
\hline
\end{tabular}




\begin{tabular}{|l|l|l|l|}
\hline Facilities and conditions at public libraries (N = 20) & $\begin{array}{l}\text { Good } \\
\mathbf{n}(\%)\end{array}$ & $\begin{array}{l}\text { Poor } \\
\mathbf{n}(\%)\end{array}$ & $\begin{array}{l}\text { No } \\
\text { comment } \\
\mathbf{n}(\%)\end{array}$ \\
\hline Quality of books & $13(65.0)$ & $6(30.0)$ & $1(5.0)$ \\
\hline Computer software such as Microsoft packages & $13(65.0)$ & $6(30.0)$ & $1(5.0)$ \\
\hline The signage in the library & $12(60.0)$ & $5(20.0)$ & $4(20.0)$ \\
\hline Computers and other related equipment & $7(35.0)$ & $12(60.0)$ & $1(5.0)$ \\
\hline Nature and ambience of the computer area & $4(20.0)$ & $10(50.0)$ & $6(30.0)$ \\
\hline Range of online databases and other resources & $3(15.0)$ & $15(75.0)$ & $2(10.0)$ \\
\hline $\begin{array}{l}\text { Quantity and quality of other collections (CDs, DVDs, } \\
\text { flash cards, audio tapes) }\end{array}$ & $1(5.0)$ & $17(85.0)$ & $2(10.0)$ \\
\hline
\end{tabular}

None of the given 30 library facilities and conditions was rated excellent although the ratings of most of the items were fairly high. The first three items rating as good were: library opening hours, an option selected by all respondents $(20,100.0 \%)$, the arrangement of books on the shelves (20,100.0\%), and hospitability and welcoming aspects of the library (19, 95.0\%). However, three items had poor ratings. These were the nature and ambience of the computer area $(10,50.0 \%)$, the range of online databases and other resources $(15,75.0 \%)$, and the quantity and quality of electronic information materials (CDs, DVDs, flash cards, audio tapes) (17, 85.0\%). The results indicate gaps in facilities, organisation, design and responsiveness of the libraries.

\section{Challenges Encountered by Public Libraries in Providing Business Information Services}

The study further wanted to understand the challenges that public libraries were facing in providing business information services to SBEs. Eleven challenges were posed to staff respondents requiring them to indicate whether a given challenge was a "major challenge", "average challenge", "minor challenge" or "was not a challenge". The responses are presented in Table 5.

Table 5: Challenges encountered by public libraries in providing business information services to SBES

\begin{tabular}{|l|l|l|l|l|}
\hline Suggested challenges $(\mathbf{N}=\mathbf{2 0})$ & $\begin{array}{l}\text { It is a } \\
\text { major } \\
\text { challenge } \\
\mathbf{n}(\%)\end{array}$ & $\begin{array}{l}\text { It is an } \\
\text { average } \\
\text { challenge } \\
\mathbf{n}(\%)\end{array}$ & $\begin{array}{l}\text { It is a } \\
\text { minor } \\
\text { challenge } \\
\mathbf{n}(\%)\end{array}$ & $\begin{array}{l}\text { It is not a } \\
\text { challenge } \\
\mathbf{n}(\%)\end{array}$ \\
\hline $\begin{array}{l}\text { SBEs are widely dispersed, hence it is } \\
\text { difficult to reach all of them }\end{array}$ & $12(60.0)$ & $8(40.0)$ & 0 & 0 \\
\hline
\end{tabular}




\begin{tabular}{|c|c|c|c|c|}
\hline Suggested challenges $(N=20)$ & $\begin{array}{l}\text { It is a } \\
\text { major } \\
\text { challenge } \\
\mathrm{n}(\%)\end{array}$ & $\begin{array}{l}\text { It is an } \\
\text { average } \\
\text { challenge } \\
\mathrm{n}(\%)\end{array}$ & $\begin{array}{l}\text { It is a } \\
\text { minor } \\
\text { challenge } \\
\mathrm{n}(\%)\end{array}$ & $\begin{array}{l}\text { It is not a } \\
\text { challenge } \\
\mathrm{n}(\%)\end{array}$ \\
\hline $\begin{array}{l}\text { Our library has limited funding to finance } \\
\text { the provision of business information } \\
\text { sources and services }\end{array}$ & $10(50.0)$ & $7(35.0)$ & 0 & $3(15.0)$ \\
\hline $\begin{array}{l}\text { Many SBEs are solely owned and } \\
\text { managed, hence they find it difficult to } \\
\text { close their business to visit places that } \\
\text { provide business information sources } \\
\text { and services }\end{array}$ & $9(45.0)$ & $10(50.0)$ & $1(5.0)$ & 0 \\
\hline $\begin{array}{l}\text { SBEs deal with diverse products } \\
\text { and services; this makes it difficult to } \\
\text { customise business information to a } \\
\text { given industry, sector or individual }\end{array}$ & $7(35.0)$ & $3(15.0)$ & $3(15.0)$ & $7(35.0)$ \\
\hline $\begin{array}{l}\text { Many small-scale business traders } \\
\text { are ignorant and are not interested in } \\
\text { business information }\end{array}$ & $7(35.0)$ & $11(55.0)$ & $10(50.0)$ & 0 \\
\hline $\begin{array}{l}\text { The staff who provide business } \\
\text { information services do not have } \\
\text { adequate business skills }\end{array}$ & $7(35.0)$ & $3(15.0)$ & $10(50.0)$ & $8(40.0)$ \\
\hline $\begin{array}{l}\text { Our library does not have adequate } \\
\text { staff for effective provision of business } \\
\text { information sources and services }\end{array}$ & $6(30.0)$ & $3(15.0)$ & $3(15.0)$ & $8(40.0)$ \\
\hline $\begin{array}{l}\text { Many small-scale business traders } \\
\text { have challenges in using the modern } \\
\text { information retrieval gadgets such as } \\
\text { mobile phones, iPads, tablets and } \\
\text { computers. }\end{array}$ & $5(25.0)$ & $14(70.0)$ & $1(5.0)$ & 0 \\
\hline $\begin{array}{l}\text { Many small-scale business traders do } \\
\text { not pay tax or trade licences and hence } \\
\text { calling them for training makes them } \\
\text { think they are being hunted }\end{array}$ & $3(15.0)$ & $1(5.0)$ & $9(45.0)$ & $7(35.0)$ \\
\hline $\begin{array}{l}\text { Many small-scale business traders are } \\
\text { illiterate hence they do not understand } \\
\text { the language used in information } \\
\text { materials and other media used for } \\
\text { disseminating business information }\end{array}$ & $2(10.0)$ & $12(60.0)$ & $6(30.0)$ & 0 \\
\hline $\begin{array}{l}\text { Business information is valuable and } \\
\text { is usually available at a cost. The cost } \\
\text { usually puts off many SBEs }\end{array}$ & $2(10.0)$ & $2(10.0)$ & $7(35.0)$ & $9(45.0)$ \\
\hline
\end{tabular}


According to the information in Table 5, the first three highly ranked challenges include SBEs being widely dispersed hence it is difficult to reach all of them, an option selected by $12(60.0 \%)$ of the respondents, limited funding (10, 50.0\%), and many SBEs being solely owned hence finding it difficult to close their businesses to visit places that provide business information sources and services, (9, 45.0\%). Similarly, three challenges had low rankings. These were tax evasion witch-hunting (3, 15.0\%), illiteracy (2, 10.0\%), and the cost of business information (2, 10.0\%). Interview data gathered from heads of public libraries further indicated other challenges such as the lack of staff training in business matters, the lack of skills of selecting business collections, a poor reading culture of the community, and poor business information retrieval skills of both SBEs and staff.

\section{Measures Needed at Public Libraries to Improve the Provision of Business Information Services}

Finally, the study sought measures to be taken that were appropriate at public libraries in order to improve the provision of business information services to SBEs. Both the SBEs and staff agreed on eight measures as shown in Table 6.

Table 6: Measures needed at public libraries to improve the provision of business information services

\begin{tabular}{|l|l|l|}
\hline Measures (N = 296 for SBEs and 20 for library staff) & $\begin{array}{l}\text { Percentages } \\
\text { of SBE } \\
\text { traders }\end{array}$ & $\begin{array}{l}\text { Percentages of } \\
\text { public libraries } \\
\text { staff }\end{array}$ \\
\hline $\begin{array}{l}\text { Have business librarians who coach, mentor and train } \\
\text { business people on how to use Internet sources for } \\
\text { information on businesses }\end{array}$ & $72.6 \%$ & $100 \%$ \\
\hline $\begin{array}{l}\text { Establish business corners or centres where all } \\
\text { information materials related to businesses are kept, and } \\
\text { related information services are offered }\end{array}$ & $69.6 \%$ & $95 \%$ \\
\hline $\begin{array}{l}\text { Conduct, coordinate or organise periodic business } \\
\text { training, workshops and seminars that are specific to } \\
\text { particular types of business community }\end{array}$ & $65.5 \%$ & $85 \%$ \\
\hline $\begin{array}{l}\text { Provide computers, iPads or tablets that are connected to } \\
\text { the Internet for the business community to use at public or } \\
\text { community libraries }\end{array}$ & $64.9 \%$ & $85 \%$ \\
\hline $\begin{array}{l}\text { Provide business consultancy, reference and referral } \\
\text { services to the small-scale business community }\end{array}$ & $62.8 \%$ & $85 \%$ \\
\hline
\end{tabular}




\begin{tabular}{|l|l|l|}
\hline Measures ( $\mathbf{N}=\mathbf{2 9 6}$ for SBEs and $\mathbf{2 0}$ for library staff) & $\begin{array}{l}\text { Percentages } \\
\text { of SBE } \\
\text { traders }\end{array}$ & $\begin{array}{l}\text { Percentages of } \\
\text { public libraries } \\
\text { staff }\end{array}$ \\
\hline $\begin{array}{l}\text { Network and collaborate with research organisations and } \\
\text { local universities for dissemination of business research } \\
\text { information and advisory services that are relevant to the } \\
\text { local business community }\end{array}$ & $55.1 \%$ & $85 \%$ \\
\hline $\begin{array}{l}\text { Organise business competition events to promote } \\
\text { business information services to the SBE traders }\end{array}$ & $54.4 \%$ & $75 \%$ \\
\hline $\begin{array}{l}\text { Provide meeting rooms where business partners can meet } \\
\text { to discuss business matters without being charged }\end{array}$ & $53.7 \%$ & $80 \%$ \\
\hline
\end{tabular}

All the suggested measures recorded high ratings from both SBEs traders and library staff; hence all of them were very significant in improving the provision of business information services at public libraries. The most significant measures were having business librarians who coach, mentor and train business people on how to use Internet sources for information on businesses, establishing business corners or centres, and conducting, coordinating or organising periodic business training, workshops and seminars. The findings provided the basis for crafting amicable solutions for public libraries in their endeavour to provide business information services to SBEs.

\section{DISCUSSION}

This study regards public libraries as community information centres hence well placed in providing business information services to the SBEs. However, the results in Table 1 show that SBEs are not frequent users of public libraries. This agrees with the findings by Odini, Otike and Kiplang'at (2012, 36). The low usage of public library services was also echoed by Okello-Obura et al. $(2007,17)$ who reported that the majority of the SBEs (62.4\%) in northern Uganda were not visiting public libraries for business information. The results point out weaknesses in the systems that support SBEs in public libraries in Kenya.

According to the results of this study, the non-use of business information services available at public libraries was attributed to predicaments such as the failure of business information sources and services to satisfy SBEs' business information needs, unawareness of places or providers of business information, the lack of information searching skills, inappropriate ICT facilities, the public libraries located too far away, and users' perception of public libraries; an observation that was as reported by OkelloObura et al. (2007, 17). Public libraries can overcome these challenges by elevating their value contributions, for example through information packaging (Sebina 2009) and changing the way they are perceived by the public. 
According to the staff working at public libraries in Meru County, the services that were being provided to SBEs were very scanty and the hours spent by staff on the same were insignificant (see Table 3 and Figure 1). This revealed glaring opportunities for public libraries to improve business information services to the SBEs, for example, developing a webpage for the business community, introducing the Ask-A-Librarian service, subscribing to online business databases, ensuring a dedicated business librarian, having regular SBE outreach activities, providing tailored business information services, and ensuring sufficient funding. These aspects provide hints to the success factors for the effective provision of business information services.

The study further found that 55 per cent of library staff members were neutral on the question of whether their library had good facilities and equipment to support information provision to the SBEs. Some key facilities such as ICT equipment were noted to be poor. The results indicated inadequate preparedness of public libraries to serve the small-scale business community. The effective and sustainable provision of business information services requires adequate facilities and equipment (Wilson 2013).

The first four statements regarding the unavailability of business information services at public libraries in Meru County were technology-related. Information gathered from staff indicated evidence of installation and usage of Wi-Fi hotspots in some public libraries. Nevertheless, users who were using these facilities in most cases were students and researchers. Only a few of the SBEs were using them for e-commerce and businessrelated activities. With the Internet emerging as one of the preferred information sources for SBEs (Gichohi, Onyancha, and Dulle 2016), there is a great need for public libraries to leverage access to the Internet for the public. Many public libraries in the USA, for example, offer free wireless Internet access within their premises to ease access to business information by SMEs (American Library Association 2015).

The results of this study pointed out the increasing need for the provision of employment or job-related information in public libraries. A similar need had been reported by the Urban Libraries Council (2007), Dos Santos (2009), OCLC (2011), Kinnell, Feather and Matthews (1994), and Milam (2008). Day (2002) noted that at the Leeds Public Library, job-seekers were asking for support from staff for background information on various organisations before attending the interviews.

It was clear that the business information services provided at public libraries in Meru County were not well-established compared to the USA, the United Kingdom, Australia, the Netherlands and Canada (Dos Santos 2009, 4-5). Some of the key inhibitors included SBEs being widely dispersed, limited funding, distance, inadequate business information searching skills, illiteracy among SBEs, poor culture of seeking information, and insufficient information retrieval equipment. Van Heerden and Krishna $(2013,6)$ reported similar challenges to the effective provision of community information services in Nigeria.

The mechanisms for providing business information services as also noted by Okello-Obura et al. $(2007,21)$ are not well established in developing countries hence 
the need to open more public libraries and establish structures for effective provision of business information. Key initiatives include ensuring availability, consistency, relevance, ease of use, and integrity of business information to the community. The SBE traders are busy people hence require quick answers to their information needs. This amplifies the indispensable need for qualified business librarians, the establishment of a business hub, periodic business training, workshops, customised business consultancy services, and the provision of free-of-charge meeting rooms at public libraries (see Table 6). Moreover, public libraries cannot be self-sufficient in the provision of effective business information services hence the need for appropriate collaborations and partnerships (Wilson and Train 2006, 9). The results point out the unexploited opportunities for public libraries in Meru County in serving the small-scale business communities.

\section{CONCLUSIONS}

The study concludes that SBEs were not regular users of public libraries owing to reasons that range from distance, time, unawareness, knowledge and inadequate facilities. It was established that SBEs require access to reliable and credible business information services for them to thrive. However, the provision of business information services in public libraries in Meru County was in a desolate state. There was conspicuous unpreparedness among public libraries which was attributed to policy issues, weak structures, inadequate funding, poor business information literacy skills, a poor reading culture, weak marketing programmes, slow embracement of technology, and a lack of profiles for the SMEs. The study has expounded the crucial role that public libraries should play in enhancing business community development and has exposed the unexploited opportunities and measures needed by public libraries in Meru County to improve the provision of business information services.

\section{RECOMMENDATIONS}

The study recommends the establishment of broad-based business information services at public libraries, and measures that would attract SBEs to utilise them. This can be realised by elevating facilities, enhancing outreach programmes, ensuring adequate funding, having good leadership, engaging qualified and knowledgeable business services librarians, seeking partnerships, employing aggressive marketing strategies, embracing ICT in service delivery, increasing coverage to the public, and by having an appropriate policy framework. Further research taking a comparative approach across different counties is recommended to encourage knowledge sharing and diffusion of best practices. 


\section{RELEVANCE/IMPLICATIONS ON POLICY AND PRACTICE}

The study has underpinned significant measures for improving the provision of business information services to SBEs by public libraries in Meru County. It contributes new knowledge in business community development by expounding the role that public libraries can play in providing holistic business information services. The study further informs the policy framework on knowledge sharing and dissemination of business information in fostering local and national economic development. It has pointed out new approaches to the provision of business information by public libraries to the SBEs.

\section{REFERENCES}

Allen, K. 2011. "Current Trends Affecting Providers of Business Information." Business Information Review 28 (1): 38-40. https://doi.org/10.1177/0266382111403851.

American Library Association 2015. “American Libraries”. Accessed 2 May 2015. http://www.ala.org/ news/sites/ala.org.news/files/content/0415_StateAmLib_0.pdf.

Carter, S., and D. Jones-Evans. 2012. Enterprise and Small Business: Principles, Practices and Policy, 3rd ed. Harlow: Pearson.

Chiware, E. R. T. 2007. "Designing and Implementing Business Information Services in the SMME Sector in a Developing Country: The Case for Namibia." IFLA Journal 33 (2): 136-44. https://doi.org/10.1177/0340035207080308.

Day, A. 2002. "Public Business Libraries: The Next Chapter." Business Information Review 19 (2): 14-20. https://doi.org/10.1177/026638202321036196.

Dos Santos, V. F. 2009. "Public Libraries and their Contribution towards Economic Development: A Discussion." Library and Information Science Research Electronic Journal 19 (2): 1-9. Accessed 28 June 2015). http://citeseerx.ist.psu.edu/viewdoc/download?doi=10.1.1.178.9167\&rep=rep1\&type $=$ pdf.

EIFL and TNS RMS East Africa. 2012. "Perception of Public Libraries in Africa." Accessed 19 June 2014. http://www.eifl.net/system/files/resources/201408/perceptions_of_public_libraries_in_africa_-_full_ report_hi.pdf.

Forsman, H., and S. Temel. 2011. "Innovation and Business Performance in Small Enterprises: An Enterprise-Level Analysis." International Journal of Innovation Management 15 (3): 641. https://doi.org/10.1142/S1363919611003258.

Gichohi, P. M., O. B. Onyancha, and F. W. Dulle. 2016. "How Public Libraries in Meru County, Kenya, address the Business Information Needs of Small-Scale Enterprises." Information Development 33 (4): 418-35. https://doi.org/10.1177/0266666916667998.

Hosono, K. 2006. "Changes in University and Public Libraries in Japan." IFLA Journal 32 (2): 119-30. https://doi.org/10.1177/0340035206066409. 
Kinnell, M., J. Feather, and G. Matthews. 1994. "Business Information Provision for Small and MediumSized Enterprises in China: The Application of Marketing Models". Library Management 15 (8): 1623. https://doi.org/10.1108/01435129410071363.

KIPPRA. 2013. Creating an Enabling Environment for Stimulating Investment for Competitive and Sustainable Counties. (Kenya Economic Report 2013). Nairobi: Government Printers.

Meru County Government. 2014. "About Meru County Government”. Accessed 26 June 2014. http://meru.go.ke/content.php?com=37\&com $2=54 \& \operatorname{com} 3=$.

Milam, D. P. 2008. "Public Library Strategies for Building Stronger Economies and Communities." National Civic Review 97 (3): 11-16. https://doi.org/10.1002/ncr.219.

Ministry of Devolution and Planning. 2013. Meru County Development Profile. Nairobi: Government Printer.

Mutshewa, A. 2009. "A Proposed Framework for Improving the Provision of Public Library Service in Botswana". Paper presented at the Botswana Library Association 2nd National Conference, Gaborone, 30 July-1 August.

Van Heerden, E., and K. Krishna. 2013. "Transforming the Dialogue with our Customers: The Evolution of our Marketing Plan." Paper presented at the 15th Annual Conference on Libraries in Dialogue for Transformation and Innovation, Cape Town, 4-11October. Accessed 19 June 2014. http://www. google.. om $/$ url? $\mathrm{sa}=\mathrm{t} \& \mathrm{rct}=\mathrm{j} \& \mathrm{q}=\&$ esrc $=\mathrm{s} \&$ source $=$ web $\& \mathrm{~cd}=1 \& \mathrm{cad}=\mathrm{rja} \&$ uact $=8 \& \mathrm{ved}=0 \mathrm{CCMQFjAA}$ \&url=http\%3A\%2F\%2Fconferences.sun.ac.za\%2Findex.php\%2Fliasa\%2Fliasa-2013\%2Fpaper\%2F download\%2F1260\%2F377\&ei=Fxh3VaDXJKH17AblooEI\&usg=AFQjCNHbGl-CUijUoZhp23DH 9smRKZK5Mg\&sig2=4zh9d8WQKgJSr-gIVjr_Qw.

Odini, S., J. Otike, and J. K Kiplang'at. 2012. "Empowering Rural Women in Kenya to Alleviate Poverty Through Provision of Information: The Case of Vihiga District in Western Province." Paper presented at the SCECSAL xxth Conference, Nairobi, 4-8 June.

Okello-Obura, C., M. K. Minishi-Majanja, L. Cloete, and J. R. Ikoja-Odongo. 2007. "Assessment of Business Information Access Problems in Uganda." The Canadian Journal of Library and Information Practice and Research 2 (2): 1-34. http://dx.doi.org/10.21083/partnership.v2i2.306.

OCLC (Online Computer Library Centre). 2011. "How Canadian Public Libraries Stack Up". Accessed 2 June 2014. http://www.oclc.org/content/dam/oclc/reports/canadastackup/214109cef_how_ libraries_stack_up.pdf.

Otike, J. 2004. "The Development of Libraries in Kenya”. Accessed 28 June 2015. http://www.ku.ac.ke/ schools/education/images/stories/research/development-of-libraries-in-kenya.pdf.

Sebina, L. 2009. "Information Centres as Thriving and Open Spaces." Paper presented at the Botswana Library Association 2nd National Conference, Gaborone, 30 July-1 August.

Smith, J. 2009. "An Infinite Number of Niches: A Model for Delivering Information Services to Small Businesses.” Business Information Review 26(4):273-78. https://doi.org/10.1177/0266382109349614. 
Ucbasaran, D., P. Westhead, M. Wright, and M. Flores. 2010. "The Nature of Entrepreneurial Experience, Business Failure and Comparative Optimism.” Journal of Business Venturing 25 (6): 541-55. https:// doi.org/10.1016/j.jbusvent.2009.04.001.

Underwood, P. 2009. "Supporting the Information Needs of Entrepreneurs in South Africa." Library Review 58 (8): 569-80. https://doi.org/10.1108/00242530910987064.

Urban Libraries Council. 2007. "Making Cities Stronger: Public Libraries Contributions to Local Economic Development. United States of America". Accessed 12 September 2015. https://www.google. com/?gws_rd=ssl\#q=Making + Cities + Stronger:+Public + Libraries + Contributions + to + Local + Econom ic + Development.

Wilson, P. 2013. "Seven Easy Steps to Supporting Small Business Start Ups and Entrepreneurs in Arizona." Accessed 2 May 2015. https://www.youtube.com/watch?v=DXYsKZ9XA5c.

Wilson, K., and B. Train. 2006. "Business Information Service Delivery within a Regional Context - The Role of Public Libraries". Business Information Review 23 (1): 50-57. https://doi.org/10.1177/0266382106063061. 